Acta vet. scand. $1984,24,21-28$.

From the Department of Microbiology and Immunology, the Norwegian College of Veterinary Medicine, Oslo, and the Norwegian Defence Microbiological Laboratory, National Institute of Public Health, Oslo, Norway.

\title{
ENTEROTOXIGENIC ESCHERICHIA COLI IN THE JEJUNUM OF PIGLETS WITH NEONATAL DIARRHEA*
}

\author{
By \\ Ørjan Olsvik and Kåre Fossum
}

OLSVIK, $\emptyset$. and K. FOSSUM: Enterotoxigenic Escherichia coli in the jejunum of piglets with neonatal diarrhea. Acta vet. scand. 1984, 25, 21-28. - Thirty-two Escherichia coli colonies were taken from the primary step of cultivation of the jejunal contents of each of 10 dead piglets which had suffered from diarrhea. The organisms of each colony were examined for the presence of adhesion fimbria (F4 (K88) and F5 (K99)), production of heat-stable and heat-labile enterotoxin and of colicins.

The presence of heat-labile enterotoxin in the intestinal content of the necropsied pigs was also tested, and results correlated with enterotoxin production of the isolated E. coli strains. In all but 3 pigs, $50-80 \%$ of the E. coli strains were found to produce one or both of the enterotoxins and to possess the F4 of the F5 antigen. All bacteria producing both heat-labile and heat-stable enterotoxin proved to belong to $O$ group 149 and to possess the F4 antigen. Strains from 1 pig belonged to $O$ group 64 and possessed the $F 5$ antigen; these bacteria produced heat-stable enterotoxin only. Most of the enterotoxin-producing $E$. coli also produced colicins.

After each subcultivation, the strains produced less heat-labile enterotoxin, some becoming negative when assayed.

Escherichia coli; enterotoxins; adhesins.

Enterotoxigenic strains of E. coli inducing diarrhea, usually possess the ability to adhere to the intestinal surface and to produce enterotoxins (Satterwith et al. 1978, Bäck et al. 1980, DeBoy et al. 1981, Lund et al. 1982, Gaastra \& Graaf 1982). The adhesive fimbria of E. coli are now regarded as cellular antigens and called $\mathrm{F}$ antigens. Thus the K88, K99 and 987P fimbria are now desig-

* This investigation was supported by the Agricultural Research Council of Norway. 


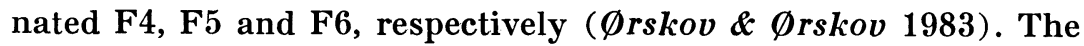
genetic information coding for adhesion and enterotoxin production is plasmid mediated (except for F6 which is of chromosomal nature) and is found in $E$. coli strains of different $O$ groups. Strains of some $O$ groups seem, however, to be more commonly associated with enterotoxicity than others. This is especially true for strains of porcine origin (Smith \& Huggins 1977, Williams et al. 1977, McDonnell et al. 1981, Franklin et al. 1981, Lund et al. 1982).

The frequency with which E. coli strains with adhesion fimbria and enterotoxin production are found in piglets suffering from neonatal diarrhea, is important for diagnostic work. In the light of reported loss of such properties (Bäck et al. 1980), the number of subcultivations before examination for these factors seems to be of interest.

The aim of this study was to investigate the proportion of E. coli strains possessing the various virulence factors, which are present in the jejunal content of piglets dying from diarrhea, and to investigate the loss during subcultivation of heat-labile enterotoxin production by the originally LT-producing strains.

\section{Bacterial strains \\ MATERIALS AND METHODS}

Thirty-two single colonies identified as lactose positive E. coli according to the criteria of Edwards \& Ewing (1972) were isolated from each of 10 piglets. The animals, which were $1-3$ days old, were from different herds, and had suffered from diarrhea. The dead animals were sent to the National Veterinary Institute, Oslo, where the necropsies were performed $1-3$ days post mortem. The jejunal contents were kept at $-20^{\circ} \mathrm{C}$ for a maximum period of 2 months before inoculation onto bromthymol blue lactose agar plates. The term "strains" is used hereafter to describe the organisms originating from each of the 32 single colonies tested from each pig. The strains were examined for $F$ antigens and enterotoxins after the first cultivation step after primary isolation. All enterotoxin positive strains were subcultivated once, twice or 3 times on lactose agar plates, with three days storage at $4^{\circ} \mathrm{C}$ between each cultivation, before broth cultivation for examination of toxin production as described by Olsvik et al. 1982. Some strains were kept on deep agar for 5 months and then cultivated and tested for enterotoxin production. 
$O$ and $F$ antigen determination

All enterotoxin producing strains were tested for the $\mathrm{O}$ group 64 and 149 antigens by the tube agglutination method (Söderlind 1971 ) and for the presence of F4 and F5 by the slide agglutination method (Ørskov \& Ørskov 1983). The strains were cultivated overnight on lactose agar plates for production of F4 and on Minca agar plates (Guinée et al. 1977) for production of F5.

\section{Colicin testing}

Production of colicin was tested by the agar plate method (Franklin et al. 1981), using 2 generally sensitive E. coli strains (ROW and 185NX) *.

\section{Enterotoxin testing}

A 4-layer enzyme-linked immunosorbent assay (ELISA) (Olsvik et al. 1982) was used for detection of heat-labile enterotoxin in the TSB growth supernatants (after 1, 2, and 3 extra lactose agar plate passages) and in sonicated extracts from the intestinal contents (Olsvik et al. 1982, Olsvik \& Fossum 1982, Olsvik \& Kapperud 1982, Olsvik \& Berdal 1982).

The infant mouse assay was used when testing for the presence of heat-stable enterotoxin using TSB growth supernatants (Dean et al. 1971).

\section{RESULTS}

Heat-labile enterotoxin was found in the jejunal contents of 6 pigs. E. coli strains producing heat-labile and heat-stable enterotoxins were detected in the same 6 pigs (no. 1-6) (Table 1). In the jejunal content of 1 pig (no. 7) strains producing heatstable enterotoxin only were found. Neither toxin nor enterotoxin producing E. coli strains were found in the jejunal contents of pig 8, 9 and 10 (Table 1).

E. coli strains producing LT, ST and F4 fimbria were isolated from the 6 piglets (no. 1-6) in which LT was detected in the jejunum. Between $16-30$ of the 32 E. coli strains tested from each pig possessed these virulence factors. These strains all belonged to $O$ group 149. Strains belonging to $O$ group 64 were found in 1 pig (no. 7), these possessed the F5 antigen and produced heat-stable enterotoxin only (Table 1 ).

* The strains were kindly supplied by E. Liven, National Veterinary Institute, Oslo. 
Table 1. E. coli heat-labile enterotoxin detected directly in the jejunal content compared with production of heat-labile (LT), heatstable (ST) enterotoxin, F4:0149 and F5:O64 antigens and colicin by 320 E. coli strains isolated from 10 pigs.

\begin{tabular}{rcccccc}
\hline \multirow{2}{*}{ Pig no. } & \multirow{2}{*}{$\begin{array}{c}\text { LT in the jejunal } \\
\text { content }\end{array}$} & \multicolumn{5}{c}{ Number of strains possessing } \\
\cline { 3 - 7 } & & O149:F4 & O64:F3 & LT + ST & Colicins & None $^{\mathrm{a}}$ \\
\hline \multirow{2}{*}{+} & 30 & 0 & 30 & 24 & 2 \\
2 & + & 16 & 0 & 16 & 16 & 5 \\
3 & + & 25 & 0 & 25 & 28 & 2 \\
4 & + & 30 & 0 & 30 & 16 & 2 \\
5 & + & 28 & 0 & 28 & 20 & 1 \\
6 & + & 26 & 0 & 26 & 19 & 3 \\
7 & - & 0 & 25 & 25 b & 21 & 1 \\
8 & - & 0 & 0 & 0 & 0 & 32 \\
9 & - & 0 & 0 & 0 & 0 & 32 \\
10 & - & 0 & 0 & 0 & 0 & 32 \\
\hline
\end{tabular}

a None of these factors.

b Heat-stable enterotoxin only.

Of the $224 \mathrm{E}$ coli strains isolated from 7 pigs (no. 1-7), 180 $(80 \%)$ were classified as possibly enteropathogenic, possessing adhesion factors and the ability to produce enterotoxin. Most of these strains also produced colicin, although this property was not strictly limited to the enterotoxigenic strains. Colicins were produced by $64.3 \%$ of the strains isolated from pigs no. $1-7$, but were not found at all in strains isolated from pigs no. 8-10.

Figure 1 shows the distribution of the 155 LT positive strains according to LT production (quantified by ELISA) after 1, 2 and 3 passages on lactose agar plates. After 2 passages, 142 strains out of 155 were still positive for LT, while after 3 passages, only 129 of the 155 originally positive strains produced detectable amounts of LT. It should be emphasised that most of the strains produced less LT after subcultivation. Some high producing strains, however, produced large amounts of LT even after several passages, and when tested after 3 months of storage.

\section{DISCUSSION}

It appears that $E$. coli strains belonging to $O$ groups 149 and 64 associated with the adhesion fimbria antigens F4 and F5 respectively, are those mainly responsible for $\mathrm{E}$. coli diarrhea in pigs in Norway at the present time (Lund et al. 1982). 


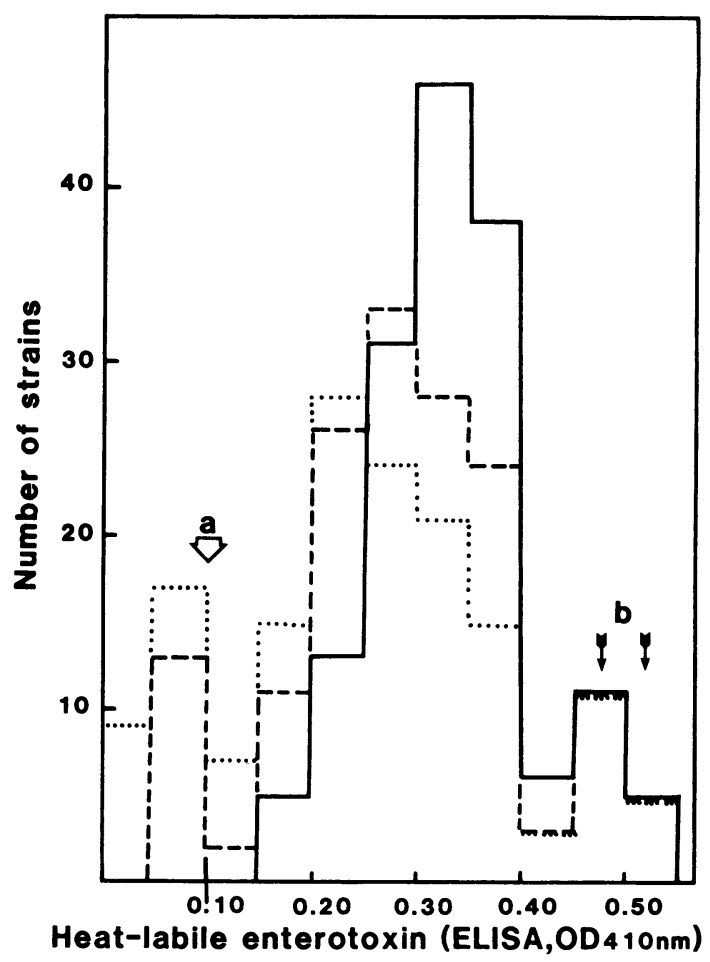

Figure 1. Distribution of 155 heat-labile enterotoxin positive strains, according to the heat-labile enterotoxin production as detected by ELISA in TSB (OD>0.10) after $1(-\ldots), 2(\ldots-)$ and $3(\ldots \ldots)$ passages on lactose agar plates. Of these strains 142 were positive after 2 cultivation steps and 129 positive after 3 cultivation steps. Arrow a indicates the limit of positivity $(O D>0.10)$, and arrows $b$ indicate the number of strains which appeared to show stable heat-labile enterotoxin production.

For diagnostic purposes, it is important to determine the frequency in which enterotoxigenic E. coli strains are found in the intestines of pigs dying from diarrhea. The present results indicate that $50-80 \%$ of the $E$. coli isolated from pigs with heat-labile enterotoxins in the jejunum contents, possess adhesive fimbria and produce enterotoxins. Reis et al. (1982) investigated E. coli strains isolated from the faeces of patients (5-10 strains from each) for enterotoxins, and Morris et al. (1976) investigated 4 lactose positive and 1 lactose negative $E$. coli strain (isolated from faeces) in a large methodological evaluation test. 
One should probably expect that the adhesin-producing strains would predominate in the jejunal content even more than the present investigation indicates. The explanation may be that these strains possess other unknown adhesion factors, or that the growth of nonadhering organisms is more favourable than of the adhesive ones in the intestines after the death of the animals.

All strains of $\mathrm{O}$ group 149 possessed F4 antigen and produced both enterotoxins, while all the strains of $O$ group 64 possessed the F5 antigen and produced the heat-stable enterotoxin only.

The amount of extracellular LT produced by these E. coli strains was reduced during extra subcultivation steps. Some strains which produced LT after the first cultivation step became negative according to the ELISA test after further subcultivations. Too many subcultivations should therefore be avoided before testing for LT production. Some of the strains seemed, however, to show stable LT production. Evans et al. (1977) divided enterotoxigenic E. coli strains into different groups according to the stability of enterotoxin production, and it seems that $\mathrm{O}$ group 149 may encompass both stable and unstable LT-producing strains.

Direct demonstration of toxins or adhesion fimbria is to be preferred, though sensitive methods are then required. ELISA has been used for the direct detection of heat-labile enterotoxin in intestinal content (Olsvik \& Fossum 1982), and for detection of F5 in faeces of pigs (Ellens et al. 1979).

Reduced LT production could be due to a high percentage of strains in the culture lacking plasmids coding for LT production, or may be simply the results of the strains producing less LT. The latter situation could possibly be induced by culture conditions.

\section{REFERENCES}

Bäck, E. R., R. Möllby, B. Kaijser, G. Stintzing, T. Wadström \& D. Habte: Enterotoxigenic Escherichia coli and other gram-negative bacteria of infantile diarrhea: surface antigens, hemagglutinins, colonization factor antigen, and loss of enterotoxigenicity. J. infect. Dis. 1980, 142, 318-327.

Dean, A. G., Y. Ching, R. G. Williams \& L. B. Harden: Test for Escherichia coli enterotoxin using infant mice: application in a study of diarrhea in children in Honolulu. J. infect. Dis. 1971, 125, $407-411$. 
DeBoy, J. M., G. M. Thorne, C. F. Deneke \& K. Wachmuth: Colonization factors and Escherichia coli belonging to enterotoxinassociated serotypes. Curr. Microbiol. 1981, 6, 49-53.

Edwards, P. R. \& W. H. Ewing: Identification of Enterobacteriaceae 3rd ed. Burgess Publishing Company, Minn., USA 1972, p. 67108.

Ellens, D. T., P. W. de Leeuw \& H. Rozemond: Detection of the K99 antigen of Escherichia coli in calf faeces by enzyme-linked immunosorbent assay (ELISA). T. Diergeneesk. 1979, 104, suppl. 4, $169-175$.

Evans, D. J., D. G. Evans, H. L. DuPont, F. Ørskov \& I. Ørskov: Patterns of loss of enterotoxicity by Escherichia coli isolated from adults with diarrhea: suggestive evidence for an interrelationship with serotype. Infect. Immun. 1977, 17, 105-111.

Franklin, A., O. Söderlind \& R. Möllby: Plasmids coding for enterotoxins, K88 antigen and colisins in porcine Escherichia coli strains of O-group 149. Med. Microbiol. Immunol. 1981, 170, $63-72$.

Gaastra, W. \& F. K. de Graaf: Host-specific fimbrial adhesins of noninvasive enterotoxigenic Escherichia coli strains. Microbiol. Rev. 1982, 42, 129-161.

Guinée, P. A. M., J. Veldkamp \& W. H. Jansen: Improved Minca medium for the detection of K99 antigen in calf enterotoxigenic strains of Escherichia coli. Infect. Immun. 1977, 15, 676-678.

Lund, A., K. Fossum \& E. Liven: Serological, enterotoxin producing and biochemical properties of Escherichia coli isolated from piglets with neonatal diarrhea in Norway. Acta vet. scand. 1982, 23, $79-87$

McDonnell, M. M., H. L. Smith, G. A. Willshaw, A. M. Field \& B. Rowe: Plasmids coding for colonization factor antigen $I$ and heatstable enterotoxin production isolated from enterotoxigenic Escherichia coli : Comparison of their properties. Infect. Immun. 1981, 32, 927-936.

Morris, G. K., M. H. Merson, D. A. Sack, J. G. Wells, W. T. Martin, W. E. Dewitt, J. C. Feeley, R. B. Sack \& D. M. Bessudo: Laboratory investigation of diarrhea in travelers to Mexico: Evaluation of methods for detecting enterotoxigenic Escherichia coli. J. clin. Microbiol. 1976, 3, 486-495.

Olsvik, Ø.\& B. P. Berdal: Demonstration of Escherichia coli heat-labile enterotoxin using bacterial cell sonicates. Acta path. microbiol. immunol. Scand. Sect. B. 1982, 90, 319-321.

Olsvik, $\emptyset . \&$ K Fossum: Demonstration of Escherichia coli enterotoxin in the jejunum contents of pigs died of diarrhea. Proc. 14th Nordic Vet. Congr., Copenhagen 1982, p. 416.

Olsvik, Ø., О. T. Hushovd, B. P. Berdal, T. Bergan \& M. Mathiesen: Production of enterotoxin by Escherichia coli at four, twentytwo and thirty-seven degrees centigrade. Eur. J clin. Microbiol. $1982,1,12-16$. 
Olsvik, Ø. \& G. Kapperud: Enterotoxin production in milk at 22 and $4^{\circ} \mathrm{C}$ by Escherichia coli and Yersinia enterocolitica. Appl. Environ. Microbiol. 1982, 43, 997-1000.

Ørskov, F. \& I. Ørskov: Serogrouping of E. coli. In: T. Bergan: Methods in Microbiology, vol 16. Academic Press, London 1983.

Reis, M. H. L., B. E. C. Guth, T. A. T. Gomes, J. Murahovschi \& L. R. Trabulsi: Frequency of Escherichia coli strains producing heatlabile toxin or heat-stable toxin or both in children with and without diarrhea in San Paulo. J. clin. Microbiol. 1982, 15, $1062-1064$.

Satterwith, T. K., D. G. Evans, H. L. DuPont \& D. J. Evans jr.: Role of Escherichia coli colonization factor antigen in acute diarrhæa. Lancet 1978, vii, 181-184.

Smith, H.W. \& M. B. Huggins: The influence of plasmid-dermined and other characteristics of enteropathogenic Escherichia coli on their ability to proliferate in the alimentary tracts of piglets, calves and lambs. J. med. Microbiol. 1977, 11, 471-492.

Söderlind, O.: Studies on Escherichia coli in pigs: II. Serological investigations. Zbl. Vet. Med. B. 1971, 18, 569-590.

Williams, P. H., M. I. Sedgwick, N. Evans, P. J. Turner, R. H. George \& A. S. McNeish: Plasmid mediated mucosal adherence in human enteropathogenic Escherichia coli. Lancet 1977, $i, 1151$.

\section{SAMMENDRAG}

Frekvens og diagnostikk av enterotoksigene Escherichia coli i tynntarmen hos gris d $\phi$ de av diare.

Tretti-to kolonier av Escherichia coli ble isolert fra tynntarmen på hver av $10 \mathrm{~d} \varnothing \mathrm{de}$ grisunger og unders $\varnothing \mathrm{kt}$ med hensyn på spesifikke fimbrier, colicin og enterotoksin-produksjon. Tarminnholdet ble også unders $\varnothing \mathrm{kt}$ direkte for tilstedeværelse av termolabilt enterotoksin (LT). Fra 4 dyr fant en ingen enterotoksin produserende E. coli, hos 6 dyr fant en LT i tynntarminnholdet, og ca $80 \%$ av E. coli koloniene var enterotoksiske for både LT og ST (termostabilt toksin). Disse bakteriene hadde også adhesjonsfimbrien F4 (K88) sammen med $O$ antigen 149. En gris hadde E. coli med $O$ antigen 64 og adhesjonsfimbrie F5 (K99). Disse dannet ikke LT, kun ST. De fleste enteropatogene E. coli var også colicin-produsenter. Etter subkultiveringer produserte stammene mindre LT, og noen som opprinnelig var positive ble etterhvert negative. Noen stammer forble imidlertid høyprodusenter av LT, selv etter mere enn 3 passasjer.

(Received December 2, 1983).

Reprints may be requested from: Ørjan Olsvik, the Norwegian Defence Microbiological Laboratory, National Institute of Public Health, Geitmyrsveien 75, Oslo 4, Norway. 